\title{
Prediksi Kadar Total Padatan Terlarut (TPT) dan Vitamin C Buah Mangga Arumanis (Mangifera indica L) Menggunakan Near Infrared Spectroscopy (NIRS) dengan Metode Partial Least Square (PLS) \\ (Prediction of Soluble Solids Content (SSC) and Vitamin C on Mangoes (Mangifera Indica L) Using Near Infrared Spectroscopy (NIRS) with Partial Least Square (PLS) Method
}

\author{
Salman Rivaldi ${ }^{1}$, Yuswar Yunus ${ }^{1}$, Agus Arip Munawar ${ }^{1 *}$ \\ ${ }^{1}$ Program Studi Teknik Pertanian, Fakultas Pertanian, Universitas Syiah Kuala \\ *Corresponding author: aamunawar@unsyiah.ac.id
}

\begin{abstract}
Abstrak. Total padatan terlarut (TPT) dan vitamin C merupakan suatu komponen penting dalam mangga. Total padatan terlarut (TPT) merupakan total unsur atau elemen mineral yang terlarut didalam suatu larutan. TPT disebut juga dengan kadar gula total, karena kualitas rasa manis dari buah diukur dengan pengukuran kadar gula. Vitamin C merupakan vitamin yang larut dalam air dan esensial untuk biosintesis kolagen. Pengukuran TPT dapat dilakukan menggunakan alat refraktometer, sedangkan vitamin C diukur menggunakan metode titrasi, serta dengan penggunaan gelombang elektromagnetik seperti NIRS. Penelitian ini bertujuan menguji dan mengevaluasi teknologi NIRS sebagai metode cepat dan tepat dalam memprediksi kandungan TPT dan vitamin C pada mangga dengan metode Partial Least Squares (PLS) serta menentukan metode koreksi spektrum yang terbaik dan akurat untuk memprediksi TPT dan vitamin C pada mangga dengan menggunakan pre-treatment Baseline Correction, dan Multiplicative Scatter Correction (MSC). Penelitian ini menggunakan buah mangga jenis Arumanis, yang berjumlah 30 sampel. Prediksi TPT dan vitamin C dengan NIRS menggunakan alat FT-IR IPTEK T-1516. Pengolahan data menggunakan Unscramble software ${ }^{\circledR} X$ version 10.5. Hasil penelitian menunjukkan prediksi TPT pada mangga dengan metode Partial Least Squares (PLS) menghasilkan sufficient performance dengan nilai RPD yang didapat yaitu 1,29 dan metode koreksi terbaik pada pendugaan TPT ialah Baseline Correction dengan nilai RPD 1,53,r sebesar 0,4783, R2 sebesar 0,5600 dan RMSEC sebesar 2,9048. Sedangkan hasil prediksi vitamin C pada mangga menghasilkan good model performance dengan nilai RPD yang didapat yaitu 2,18 dan metode koreksi terbaik pada pendugaan vitamin C ialah MSC dengan nilai RPD 2,36, r sebesar 0,9026, R2 sebesar 0,8147 dan RMSEC sebesar 4,4067.
\end{abstract}

Kata kunci : NIRS, PLS, Pretreatment, Baseline Correction, MSC.

\begin{abstract}
Soluble solids content (SSC) and vitamin C are important components in mangoes. Soluble solids content (SSC) is the total element or mineral element dissolved in a solution. SSC is also called total sugar content, because the quality of the sweet taste of the fruit is measured by measuring the total sugar. Vitamin C is a watersoluble vitamin and essential for collagen biosynthesis. Measurement of SSC can be done using a refractometer, while vitamin $\mathrm{C}$ is measured using the titration method, and by the use of electromagnetic waves such as NIRS. This study aims to test and evaluate NIRS technology as a fast and appropriate method in predicting the content of SSC and vitamin C in mangoes using the Partial Least Squares (PLS) method and determining the best and accurate spectrum correction method to predict SSC and vitamin C in mango by using pre-treatment Baseline Correction, and Multiplicative Scatter Correction (MSC). This study used Arumanis mangoes, which amounted to 30 samples. Prediction of TPT and vitamin C with NIRS using FT-IR tool of Science and Technology T-1516. Processing data using the Unscramble software ${ }^{\circledR} \mathrm{X}$ version 10.5. The results showed that the prediction of SSC on mangoes using the Partial Least Squares (PLS) method resulted in sufficient performance with the obtained RPD value is 1,29 and the best correction method in estimating SSC is Baseline Correction with a value of RPD is $1,53, \mathrm{r}$ is $0,4783, \mathrm{R} 2$ is 0,5600 and RMSEC is 2,9048 . While the prediction results of vitamin $\mathrm{C}$ on mangoes obtain a good performance model with the value of RPD obtained is 2,18 and the best correction method for estimating vitamin $\mathrm{C}$ is MSC with a value of RPD is 2,36, $\mathrm{r}$ is $0,9026, \mathrm{R} 2$ is 0,8147 and RMSEC is 4,4067 .
\end{abstract}

Keywords: NIRS, PLS, Pretreatment, Baseline Correction, MSC. 


\section{PENDAHULUAN}

Mangga (Mangifera indica L) merupakan buah tropis yang populer di dunia, selain karena rasanya yang lezat jika dikonsumsi dalam keadaan segar atau dalam bentuk olahan, juga karena mengandung banyak nutrisi. Mangga merupakan salah satu buah tropis yang berpotensi untuk dikembangkan. Berdasarkan data Badan Pusat Statistik (2017), roduksi mangga di Indonesia tahun 2017 mencapai 2.203.789 ton atau meningkat sebesar $21.45 \%$ dari tahun 2016 yaitu sebesar 1.814.540 ton dengan luas panen 201.080 ha.

Kualitas buah mangga dinilai berdasarkan parameter eksternal seperti warna permukaan, ukuran dan bentuk serta atribut internal (Xudong et al., 2009). Penentuan kandungan kimia dalam buah tidak dapat dilihat secara visual. Oleh karena itu, diperlukan pengembangan metode yang efisien dan non-destrukif untuk mengevaluasi kualitas internal buah. Salah satu metode yang potensial adalah dengan NIR spektroskopi.

NIRS (near infrared spectroscopy) merupakan salah satu metode deteksi mutu buah secara non-destruktif yang pada saat ini mulai berkembang. ). Untuk mendapatkan informasi yang diinginkan dari spektrum NIRS, maka ditentukan oleh kualitas spektrum yang dihasilkan dan metode kalibrasi yang digunakan untuk menganalisa spektrum.

PLS merupakan metode analisa kuantitatif yang paling banyak direferensikan. Hal ini dikarenakan PLS berfokus pada kovarians diantara respond dan prediktor-prediktor yang mereduksi dampak dari banyaknya prediktor yang tidak relevan dengan keragaman data, sehingga PLS mampu bekerja lebih optimal untuk menghasilkan model prediksi yang baik (Zulfahrizal et al., 2016). Penelitian ini bertujuan untuk mengaplikasikan metode Partial Least Square (PLS) dalam menduga kualitas internal buah mangga dan membandingkan data hasil prediksi dengan data hasil uji laboratorium.

\section{METODE PENELITIAN}

\section{Waktu dan Tempat}

Penelitian ini dilaksanakan pada bulan September - Oktober 2018 di Laboratorium Instrumentasi dan Energi, Program Studi Teknik Pertanian dan Laboratorium Analisis Pangan, Jurusan Teknologi Hasil Pertanian, Fakultas Pertanian Universitas Syiah Kuala, Darussalam Banda Aceh.

\section{Alat dan Bahan}

Alat yang digunakan pada penelitian ini adalah FT-IR IPTEK T-1516 untuk pengukuran spektrum dan software ${ }^{\circledR}$ Unscramble $\mathrm{X}$ version 10.5 untuk mengolah data. Bahan yang digunakan pada penelitian ini adalah 30 buah mangga varietas arumanis.

\section{Persiapan Mangga}

Buah mangga varietas mangga arumanis dipisahkan menjadi 3 kategori berdasarkan tingkat kematangan yang terdiri dari 10 mangga matang, 10 buah mangga setengah matang dan 10 buah mangga belum matang..

\section{Akuisisi Spektrum NIRS}

Pengambilan spektrum buah mangga menggunakan alat NIRS yaitu FT-IR IPTEK T1516. Dilakukan dengan cara memberikan cahaya terhadap masing-masing sampel mangga.

\section{Pengukuran TPT Di Laboratorium}

Total padatan terlarut diukur dengan menggunakan alat refraktometer. Bahan terlebih dahulu dihaluskan dengan cara ditumbuk. Setelah itu, cairan dari sampel yang telah ditumbuk 
diletakkan diatas obyek gelas yang terdapat pada alat sehingga total padatan terlarut akan terbaca langsung pada display dalam satuan ${ }^{\circ}$ Brix. Pengukuran Vitamin C Di Laboratorium

Kadar vitamin $\mathrm{C}$ pada buah mangga ditentukan secara titrasi dengan menggunakan larutan Iodin $0,01 \mathrm{~N}$, dimana $1 \mathrm{~mL}$ larutan iodin $0,01 \mathrm{~N}=0,88 \mathrm{mg}$ asam askorbat (Slamet $e t$ al., 1989).

\section{Analisa Spektrum NIRS Mangga Arumanis}

Data spektrum hasil akuisisi kemudian dianalisa meliputi: (1) outlier removal dengan metode Principal Component Analysis (PCA). (2) Koreksi dan perbaikan data spektrum menggunakan Baseline Correction dan Multiplicative Scatter Correction (MSC). Analisa ini dilakukan dengan tujuan untuk menghilangkan noise pada spektrum akibat interferensi dan scattering photon, serta pengaruh over-heat (Munawar et al., 2013).

\section{Pembuatan Model Kalibrasi}

TPT dan vitamin $\mathrm{C}$ mangga diprediksi dengan cara membangun model kalibrasi berdasarkan data dari akuisisi spektrum NIRS yang akan dijadikan sebagai variabel $\mathrm{X}$, sedangkan data TPT dan vitamin $\mathrm{C}$ dari hasil pengukuran di laboratorium akan dijadikan sebagai variabel Y. Model prediksi dibangun dengan menggunakan metode partial least square (PLS).

\section{HASIL DAN PEMBAHASAN}

\section{Reflektan Near Infrared Mangga}

Perangkat FT-IR IPTEK T-1516 menghasilkan data pengukuran berupa data pantulan (reflektan) radiasi NIR dengan panjang gelombang $1000-2500 \mathrm{~nm}\left(4000-10.000 \mathrm{~cm}^{-1}\right)$, dimana setiap spektrum gelombang terdiri dari 1557 data dengan beberapa puncak dan lembah spektrum.

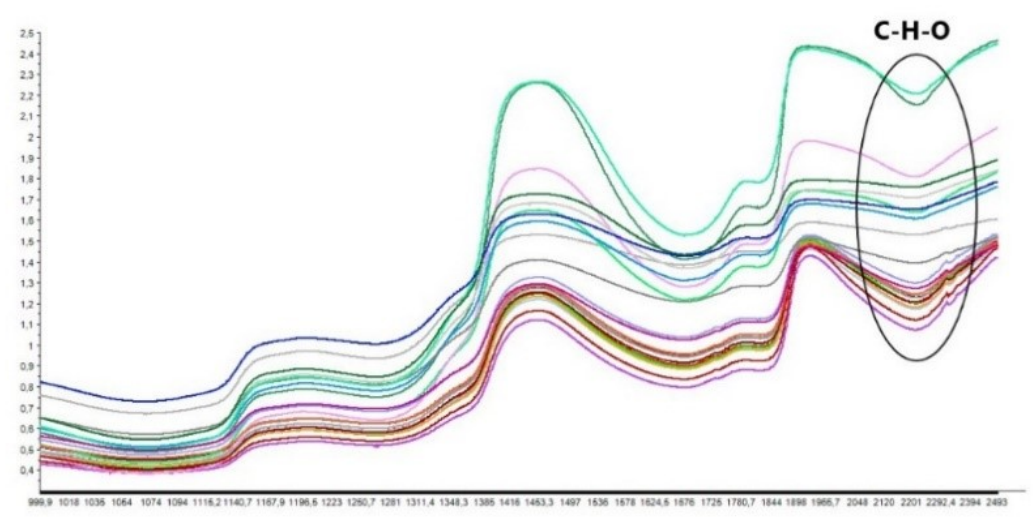

Gambar 1. Kurva Spektrum Reflektan Raw (Awal) NIR pada 30 Sampel Mangga

Osborne et al. (1993) menjelaskan bahwa puncak dan lembah yang terjadi pada spektrum diinterpretasikan bahwa memiliki kandungan kimia yang berbeda-beda. Lembah-lembah penyerapan pada spektra reflektan NIR buah mangga terjadi antara panjang gelombang 1416$1494 \mathrm{~nm}, 1638-1727 \mathrm{~nm}, 1894-1937 \mathrm{~nm}$, dan 2200-2292 nm.

Berdasarkan Cen dan He (2007), diketahui bahwa pada spektrum mangga terdapat ikatan molekul C-H-O yang mengindikasikan adanya kandungan TPT dan vitamin $\mathrm{C}$ yaitu terdapat pada panjang gelombang 2200-2292 nm. 


\section{Analisa Data Outlier}

Selanjutnya adalah mendeteksi keberadaan data outlier/pencilan dengan metode PCA (Principal Componet Analysis) yang dikombinasikan dengan Hotelling $T^{2}$ ellipse yang dapat dilihat pada Gambar 2.

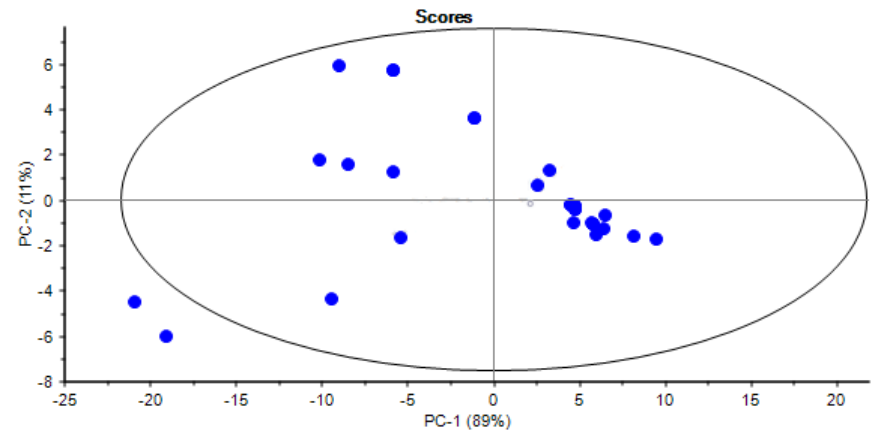

Gambar 2. Analisa Data Outlier/ Pencilan

Data outlier ialah data yang berbeda dengan data-data lainnya yang berada di luar garis elipse. Setelah analisa data outlier/pencilan dilakukan, data tersebut bukan termasuk kedalam data pencilan melainkan data pengungkit hal tersebut dikarenakan saat data diluar garis ellipse di hapus (remove) maka data yang lain ikut keluar dari garis ellipse, sehingga data yang digunakan yaitu 30 sampel.

\section{Pengolahan Data Spektrum NIR}

Pengolahan data spektrum NIR dilakukan untuk mengurangi pengaruh noise (gangguan) pada spektrum supaya diperoleh model yang lebih akurat (Munawar, 2008). Metode pretreatment spektrum yang digunakan adalah Baseline Correction dan Multiplicative Scatter Correction (MSC) sedangkan untuk model kalibrasi yang digunakan adalah Partial Least Square (PLS).

\section{Baseline Correction}

Kurva spektrum reflektan NIR buah mangga dengan perlakuan data Baseline Correction dapat dilihat pada Gambar 3.

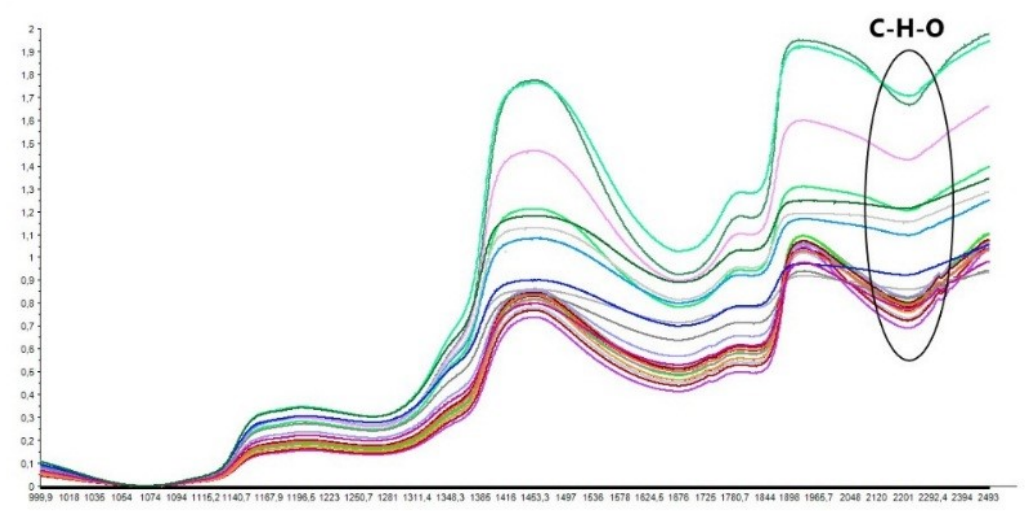

Gambar 3. Kurva Spektrum Baseline Correction

Baseline Correction berhasil menghasilkan spektrum tidak jauh berbeda dari spektrum raw, namun terlihat spektrum menjadi lebih rapat dan rapi. TPT dan vitamin $\mathrm{C}$ terdapat pada kisaran panjang gelombang 2200-2292 nm yang ditandai dengan ikatan molekul C-H-O. 


\section{Multiplicative Scatter Correction (MSC)}

Spektrum hasil mangga hasil perlakuan MSC dapat dilihat pada gambar 4 sebagai berikut.

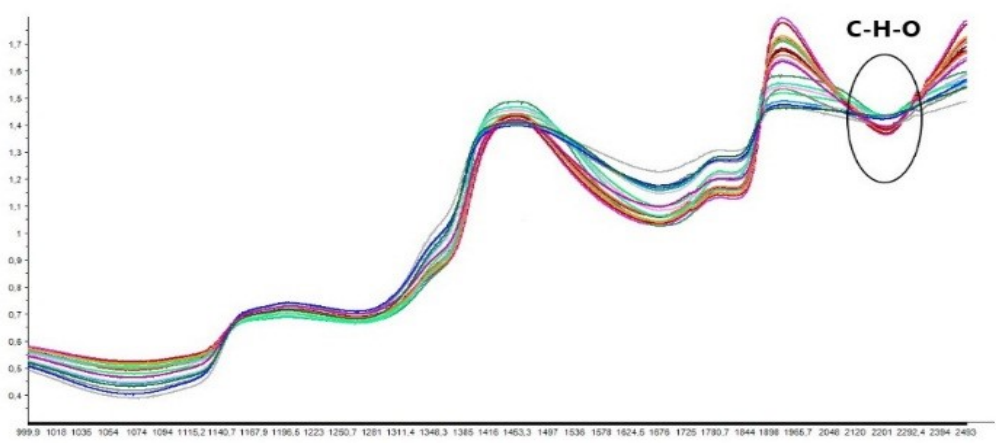

Gambar 4. Kurva Spektrum Multiplicative Scatter Correction (MSC)

Pada Gambar 4 terlihat spektrum lebih rapat. Terdapat beberapa puncak gelombang yang menunjukkan adanya kandungan kimia. TPT dan vitamin $\mathrm{C}$ terdapat pada kisaran panjang gelombang 2200-2292 nm yang ditandai dengan ikatan molekul C-H-O.

\section{Penerapan Model Kalibrasi Partial Least Squares (PLS)}

Model regresi PLS mencari korelasi antara variable x yang didapat dari akuisisi spektrum NIRS dan variabel y diperoleh dari hasil pengukuran laboratorium. Data kimia (referensi) yang terdiri total padatan terlarut dan vitamin $\mathrm{C}$ buah mangga dapat dilihat pada Tabel 1 .

Tabel 1. Data Kimia TPT dan Vitamin C Buah Mangga

\begin{tabular}{lccccc}
\hline Parameter & $\begin{array}{c}\text { Jumlah } \\
\text { Data }\end{array}$ & $\begin{array}{c}\text { Minima } \\
1\end{array}$ & $\begin{array}{c}\text { Maksima } \\
1\end{array}$ & $\begin{array}{c}\text { Rata- } \\
\text { rata }\end{array}$ & $\begin{array}{c}\text { Standar } \\
\text { Deviasi }\end{array}$ \\
\hline TPT $\left({ }^{0}\right.$ Brix $)$ & 30 & 9,06 & 22,53 & 14,8583 & 4,4545 \\
$\begin{array}{l}\text { Vitamin C } \\
(\mathrm{mg} / 100 \text { gram })\end{array}$ & 30 & 30,72 & 73,18 & 56,8564 & 10,4142 \\
\hline
\end{tabular}

Sumber : Data Laboratorium, 2018

Dari Tabel 1, dapat dilihat bahwa nilai TPT berkisar dari 9,06-22,53 ${ }^{0}$ Brix dan vitamin $\mathrm{C}$ berkisar dari 30,72 - 73,18 mg/100gram yang diperoleh dari hasil analisis laboratorium.

\section{Hasil Kalibrasi Kandungan Mangga Arumanis}

Tingkat keakuratan prediksi kadar kandungan mangga dievaluasi dengan melihat parameter statistik seperti, koefisien korelasi (r), koefisien determinasi ( $\left.\mathrm{R}^{2}\right)$, Root Mean Square Error Calibration (RMSEC), Residual Predictive Deviation Index (RPD), dan jumlah Latent Variable (LV). 


\section{Hasil Kalibrasi untuk TPT}

Hasil kalibrasi untuk TPT dapat dilihat pada gambar sebagai berikut.

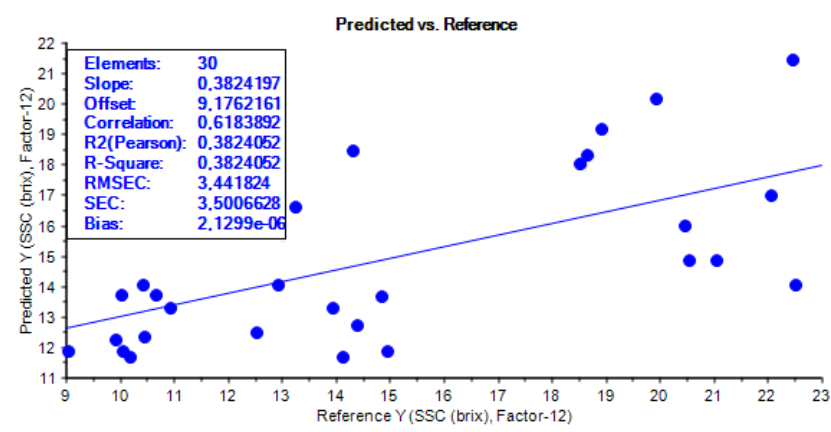

Gambar 5. Plot Data Kalibrasi TPT Non Pre-treatment

Berdasarkan Gambar 5 diatas, hasil prediksi dari spektrum awal (raw) yang belum diberikan perlakuan menghasilkan nilai koefisien korelasi (r) sebesar 0,6183 dan koefisien determinasi $\left(\mathrm{R}^{2}\right)$ 0,3824. Sedangkan nilai standar error (RMSEC) yang didapatkan yaitu sebesar 3,4418.

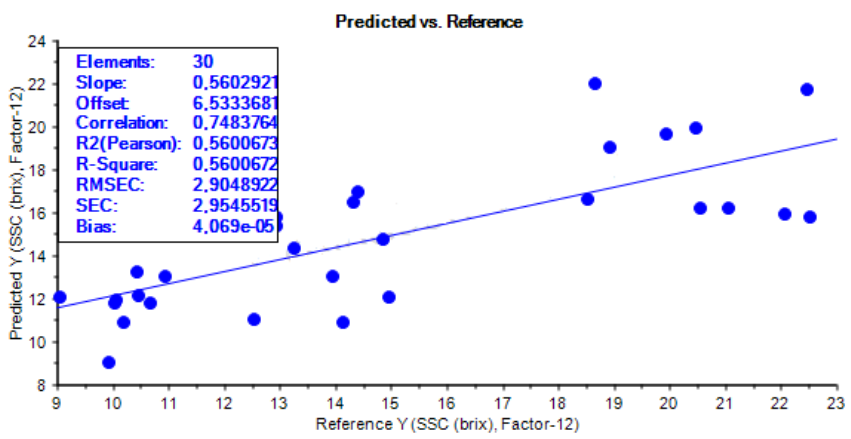

Gambar 6. Plot Data Kalibrasi TPT Pre-treatment Baseline Correction

Pada Gambar 6, terlihat bahwa hasil prediksi TPT menggunakan pre-treatment baseline correction diperoleh nilai koefisien korelasi ( $\mathrm{r}$ ) sebesar 0,7483 , koefisien determinasi $\left(\mathrm{R}^{2}\right)$ sebesar 0,5600 dan standar error (RMSEC) sebesar 2,9048.

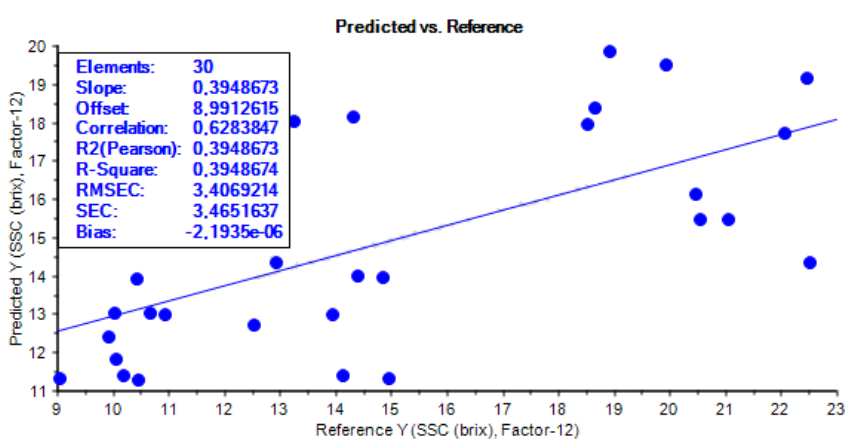

Gambar 7. Plot Data Kalibrasi TPT Pre-treatment MSC

Gambar 7 menunjukkan bahwa hasil pendugaan TPT menggunakan pre-treatment MSC memberikan nilai koefisien korelasi (r) sebesar 0,6284, koefisien determinasi $\left(\mathrm{R}^{2}\right)$ sebesar 0,3948 dan standar error (RMSEC) sebesar 3,4069.

Dari data tersebut diketahui bahwa model terbaik untuk prediksi TPT ialah pre-treatment baseline correction. Dapat dilihat pada Tabel 2. 
Tabel 2. Parameter Statistik Hasil Kalibrasi TPT pada Mangga

\begin{tabular}{lccccc} 
Perlakuan & Latent variable & $\mathrm{R}^{2}$ & $\mathrm{r}$ & $\mathrm{RMSEC}(\%)$ & $\mathrm{RPD}$ \\
\hline Non Pre-treatment & 12 & 0,3824 & 0,6183 & 3,4418 & 1,29 \\
Baseline Correction & 12 & 0,5600 & 0,7483 & 2,9048 & 1,53 \\
Multiplicative Scatter Correction & 12 & 0,3948 & 0,6284 & 3,4069 & 1,30 \\
\hline
\end{tabular}

Sumber : Hasil Penelitian, 2018

Baseline correction merupakan pre-treatment terbaik dalam memprediksi TPT pada mangga, dikarenakan nilai $\mathrm{R}^{2}$ yang dihasilkan lebih tinggi yaitu 0,5600 , kemudian nilai RMSEC yang paling rendah yaitu 2,9048 dan nilai RPD 1,53 yang merupakan nilai RPD paling tinggi. Berdasarkan nilai tersebut, Nicolai (2007) menyatakan bahwa model yang dihasilkan tergolong sebagai sufficient performance.

Hasil Kalibrasi Untuk Vitamin C

Hasil kalibrasi untuk vitamin $\mathrm{C}$ dapat dilihat pada gambar sebagai berikut.

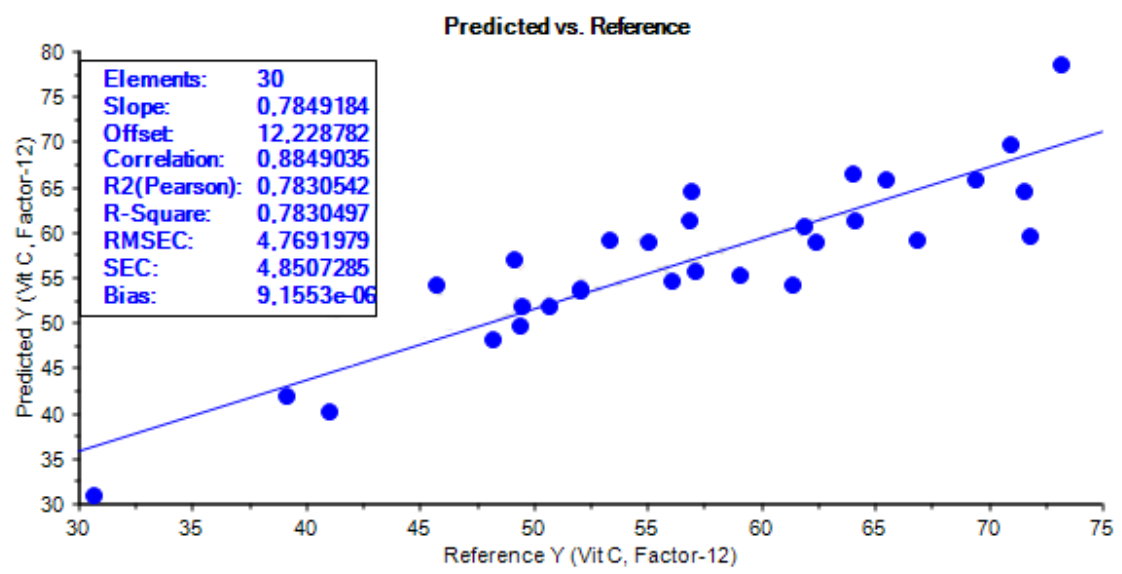

Gambar 8. Plot Data Kalibrasi Vitamin C Non Pre-treatment

Pada gambar 8 , terlihat bahwa hasil prediksi vitamin $\mathrm{C}$ tanpa pre-treatment diperoleh nilai koefisien korelasi (r) sebesar 0,8849, koefisien determinasi $\left(\mathrm{R}^{2}\right)$ sebesar 0,7830 dan standar error (RMSEC) sebesar 4,7691.

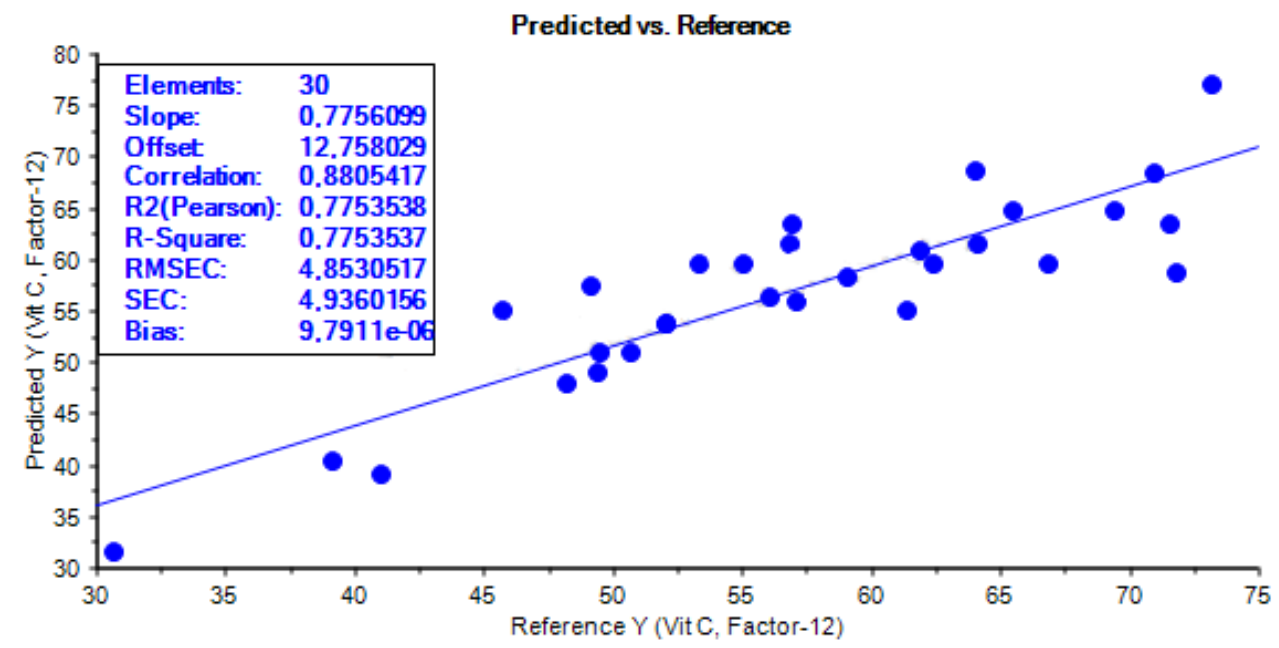

Gambar 9. Plot Data Kalibrasi Vitamin C Pre-treatment Baseline Correction 
Gambar 9 memperlihatkan hasil pendugaan vitamin $\mathrm{C}$ menggunakan pre-treatment baseline correction memberikan nilai koefisien korelasi (r) 0,8805 , koefisien determinasi $\left(\mathrm{R}^{2}\right)$ 0,7753 dan standar error (RMSEC) 4,8530.

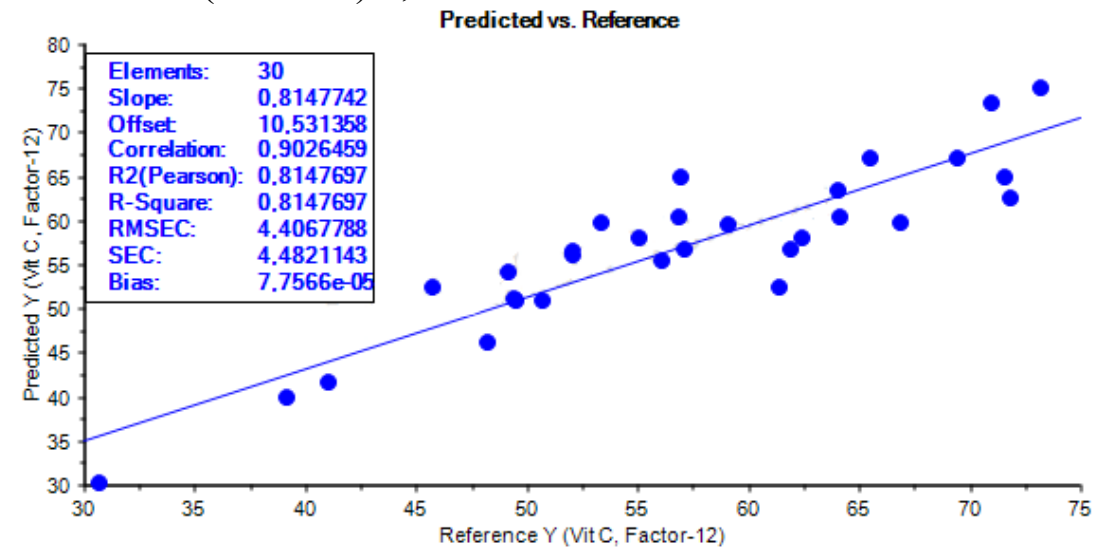

Gambar 10. Plot Data Kalibrasi Vitamin C Pre-treatment MSC

Berdasarkan gambar 10 diatas, hasil prediksi dari perlakuan MSC menghasilkan nilai koefisien korelasi (r) 0,9026 dan koefisien determinasi $\left(\mathrm{R}^{2}\right)$ sebesar 0,8147. Sedangkan nilai standar error (RMSEC) yang didapatkan 4,4067.

Secara keseluruhan data dapat dilihat pada Tabel 3 yang menunjukkan nilai parameter statistik hasil kalibrasi.

Tabel 3. Parameter Statistik Hasil Kalibrasi Vitamin C pada Mangga

\begin{tabular}{lccccc}
\hline Perlakuan & Latent variable & $\mathrm{R}^{2}$ & $\mathrm{r}$ & RMSEC (\%) & $\mathrm{RPD}$ \\
\hline Non Pre-treatment & 12 & 0,7830 & 0,8849 & 4,7691 & 2,18 \\
Baseline Correction & 12 & 0,7753 & 0,8805 & 4,8530 & 2,14 \\
Multiplicative Scatter Correction & 12 & 0,8147 & 0,9026 & 4,4067 & 2,36 \\
\hline
\end{tabular}

Sumber : Hasil Penelitian, 2018

MSC merupakan pre-treatment terbaik dalam memprediksi vitamin $\mathrm{C}$ pada mangga, dikarenakan nilai $\mathrm{R}^{2}$ yang dihasilkan lebih tinggi yaitu 0,8147 , nilai RMSEC yang paling rendah yaitu 4,4067 dan nilai RPD yaitu 2,36 yang merupakan nilai RPD paling tinggi. Berdasarkan nilai tersebut, Nicolai (2007) menyatakan bahwa model yang dihasilkan tergolong sebagai good model performance. 


\section{KESIMPULAN DAN SARAN}

\section{Kesimpulan}

Adapun berdasarkan penelitian yang telah dilakukan maka dapat diperoleh kesimpulan sebagai berikut :

1. NIRS dapat menentukan kadar nilai TPT dan vitamin C buah mangga dikarenakan menggunakan kombinasi linier untuk menduga variabel bebas (data akuisisi NIR) dari variabel terikat (data kimia).

2. NIRS dapat memprediksi kadar TPT dan vitamin $\mathrm{C}$ buah mangga dengan mengambil asumsi bahwa variabel yang memperlihatkan korelasi yang tinggi dari variabel bebas diberi bobot yang lebih besar karena variabel tersebut akan lebih efektif dalam pendugaan.

3. Terdapat korelasi yang kuat antara metode uji TPT laboratorium dan metode prediksi TPT NIRS mangga arumanis dengan nilai korelasi (r) tertinggi yaitu 0,7483 dan korelasi yang sangat kuat antara metode uji vitamin $\mathrm{C}$ laboratorium dan metode prediksi vitamin C NIRS mangga arumanis dengan nilai korelasi (r) tertinggi yaitu 0,9026. Pre-treatment terbaik pada prediksi kadar TPT mangga arumanis adalah Baseline Correction dengan nilai RPD 1,53 tergolong sebagai Sufficient Performance. Sedangkan pada prediksi kadar vitamin $\mathrm{C}$ adalah Multiplicative Scatter Correction (MSC) dengan nilai RPD 2,36 tergolong sebagai Good Model Performance.

\section{Saran}

Adapun saran yang dapat diberikan berdasarkan penelitian ini ialah sebaiknya dilakukan dengan menggunakan metode kalibrasi Non-linear untuk meningkatkan nilai RPD agar evaluasi penelitian ini akan mendapatkan hasil prediksi yang lebih akurat serta menggunakan metode Pre-treatment yang lain dan jumlah sampel penelitian ditambah guna menghasilkan nilai korelasi (r) yang lebih tinggi untuk kalibrasi TPT.

\section{DAFTAR PUSTAKA}

Andasuryani, Purwanto Y.A., I.W. Budiastra, and K. Syamsu. 2014. Determination of catechin content in gambir powder from dried gambir leaves quickly using FT NIR PLS model. International Advanced Science Engineering Information Technology. 4(5): 20885334.

Badan Pusat Statistik dan Direktorat Jendral. 2017. Produksi Mangga Menurut Provinsi Tahun 2013-2017. Kementrian Pertanian Republik Indonesia.

Cen, H dan Y. He. 2007. Theory and application of near inrfrared reflectance spectroscopy in determination of food quality. J. Trends in Food Sci \& Technol 18: 72-83.

Florez, K., M.T. Sanchez, D. Perez-Marin, J.E. Guerrero, and A.G. Varo. 2009. Feasibility in NIRS Instrument for predicting internal quality in intact tomato. Journal Food Engineering. 91:311-318.

Jha, S.N., A.R.P. Kinsly, and S. Chopra. 2006. Non-destruktif determination of firmness and yellowness of mango during growth and storage using visual spectroscopy. Journal Biosystem Engineering. 94:397-402

Mohsenin N.N. 1984. Electromagnetic Radiation Properties of Foods and Agricultural Products. Gordon and Breach Science Publishers. United Kingdom (UK).

Mouazen A.M., W. Saeys, J. Xing, De Baerdemaeker, J and H. Ramon. 2005. Near infrared spectroscopy for agricultural materials: an instrument comparison. Journal of Near Infrared Spectroscopy. 13: 87-97.

Munawar, A.A. 2008. Non-destruktif inner quality prediction in intact mangos with nirs 
methods [Thesis]. Goettingen: Georg-August University.

Munawar, A.A., D.v. Hoersten, E. Pawelzik, J.K. Wegener and D. Moerlein. 2013. Prediction of quality attributes using near infrared spectroscopic data combined with multivariate analysis. Annual Conference 33rd Gesselschaft Fuer Informatik (German Association of Informatics Enginner). Potsdam, 20-22 February 2013.

Nicolai, B.M., K. Beullens, E. Bobelyn, A. Peirs, W. Saeys, K.I. Theron and J. Lammertyn. 2007. Nondestructive measurement of fruit and vegetable quality by means of NIR spectroscopy: A Review. Postharvest Biology and Technology. 46: 99-118.

Osborne, B.G., T. Fearn, and P.H. Hindle. 1993. Partical NIR Spectroscopy With Applications In Food And Beverage Analysis. Ed ke-2. Longman Scientific Technical. New York.

Slamet, S., H. Bambang, dan Suhardi. 1989. Analisa Bahan Makanan dan Pertanian. Liberty Yogyakarta dan Universitas Gadjah Mada. Yogyakarta.

Xudong, S., Z. Hailiang, and L. Yande. 2009. Nondestructive assessment of quality of nanfeng mandarin fruit by a portable near infrared spectroscopy. International Journal of Agricultural and Biological Engineering. 2 (1):65-71.

Zulfahrizal., A.A. Munawar dan H. Meilina. 2016. Estimasi kandungan lemak pada biji kakao utuh secara cepat dan non-destruktif dengan menggunakan teknologi NIRS. Jurnal Otomasi, Kontrol dan Instrumentasi. Vol. 8(1). Hal 17. 